\title{
Article \\ Selection of Eucalyptus camaldulensis Families for Sustainable Pulpwood Production by Means of Anatomical Characteristics
}

\author{
Ikumi Nezu ${ }^{1}$, Futoshi Ishiguri ${ }^{1, *}$, Haruna Aiso ${ }^{2}$, Sapit Diloksumpun ${ }^{3}$, Jyunichi Ohshima ${ }^{1}$, Kazuya Iizuka ${ }^{1}$ and \\ Shinso Yokota ${ }^{1}$ \\ 1 School of Agriculture, Utsunomiya University, Utsunomiya 321-8505, Japan; zoo-sk3.primo@outlook.jp (I.N.); \\ joshima@cc.utsunomiya-u.ac.jp (J.O.); kiizuka@cc.utsunomiya-u.ac.jp (K.I.); \\ yokotas@cc.utsunomiya-u.ac.jp (S.Y.) \\ 2 Faculty of Agricultural Production and Management, Shizuoka Professional University of Agriculture, \\ Iwata 438-0803, Japan; aiso.haruna@spua.ac.jp \\ 3 Faculty of Forestry, Kasetsart University, Bangkok 10900, Thailand; fforspd@ku.ac.th \\ * Correspondence: ishiguri@cc.utsunomiya-u.ac.jp; Tel.: +81-28-649-5541
}

check for updates

Citation: Nezu, I.; Ishiguri, F.; Aiso, H.; Diloksumpun, S.; Ohshima, J.; lizuka, K.; Yokota, S. Selection of Eucalyptus camaldulensis Families for Sustainable Pulpwood Production by Means of Anatomical Characteristics. Forests 2021, 12, 31. https://doi.org/ f12010031

Received: 4 December 2020

Accepted: 24 December 2020

Published: 29 December 2020

Publisher's Note: MDPI stays neutral with regard to jurisdictional claims in published maps and institutional affiliations.

Copyright: () 2020 by the authors. Licensee MDPI, Basel, Switzerland. This article is an open access article distributed under the terms and conditions of the Creative Commons Attribution (CC BY) license (https: / / creativecommons.org/ licenses/by/4.0/).

\begin{abstract}
Sustainable pulpwood production from fast-growing tree plantations is needed for pulp and paper industries. To increase the pulpwood production efficiency, the anatomical characteristics and derived-wood properties of 75 trees from 15 half-sib families of Eucalyptus camaldulensis Dehnh. planted in Thailand were investigated, and then the family was classified by suitability of wood as raw material for pulp and paper products using principal component analysis and clustering. The mean values of vessel diameter, vessel frequency, fibre diameter, fibre lumen diameter, and fibre wall thickness at $2 \mathrm{~cm}$ from the cambium were $128 \mu \mathrm{m}, 16$ no. $/ \mathrm{mm}^{2}, 11.1 \mu \mathrm{m}, 7.1 \mu \mathrm{m}$, and $1.88 \mu \mathrm{m}$, respectively. In addition, the Runkel ratio, Luce's shape factor, flexibility coefficient, slenderness ratio, solids factor, and wall coverage ratio (i.e., derived-wood properties) were $0.53,0.42,0.64,85.3$, $68 \times 10^{3} \mu^{3}$, and 0.34 , respectively. Significant differences in fibre diameter, fibre lumen diameter, and Runkel ratio were found among families. Although significant differences among families were not found for other anatomical characteristics and derived-wood properties, the $p$-values obtained by an analysis of variance test ranged from 0.050 to 0.088 . Based on the results of a principal component analysis and cluster analysis, 15 families were classified into four clusters with different expected pulp and paper characteristics. The suitability of wood from E. camaldulensis half-sib families for pulp and paper can be evaluated by principal component analysis using anatomical characteristics and physical properties as variables. Based on the results, desirable pulp and paper quality may be obtained through the selection of families from this species.
\end{abstract}

Keywords: vessel morphology; fibre morphology; Runkel ratio; pulp and paper quality

\section{Introduction}

Pulpwood is one of the important forest products. According to the FAO (Food and Agriculture Organization of the United Nations) statistics [1], quantities of production in "pulpwood, round and split, all species" category were 601,836,690 m in 2010 and $708,640,761 \mathrm{~m}^{3}$ in 2019, showing an increase in production of $17.7 \%$ from 2010 to 2019. This fact indicates that the demand for pulpwood will still increase in the world. To meet this demand, plantation forestry using fast-growing tree species, such as Eucalyptus spp., Populus spp., Acacia spp., and Pinus spp., have played an important role for the sustainable supply of pulpwood [2].

Eucalyptus plantations covered 18 million hectares in Africa, Asia, North and Central America, Oceania, and South America in 2000 [3]. Of the Eucalyptus species, Eucalyptus camaldulensis Dehnh. is naturally distributed in Australia, and it is extensively planted from tropical to temperate zones [4]. The wood from this species is mainly used as raw material for pulp and paper products. In Thailand, E. camaldulensis trees have been harvested for 
pulp production, with a short rotation from 5 to 10 years after planting $[5,6]$. To increase the wood yield of this species, tree breeding programmes focusing on growth characteristics have been conducted [6,7]. However, these breeding programmes do not aim to improve wood quality in order to improve pulp and paper quality.

It is known that pulp and paper quality is influenced by anatomical characteristics and wood properties [8,9]. Fibre wall thickness is one of the most important factors because it is closely related to pulp yield, sheet density, and paper strength [9]. A vessel element with a large diameter and long length causes vessel picking, in which a vessel element is picked from the surface of paper during printing, leading to inferior paper [8]. In previous studies, to facilitate the evaluation of pulp and paper quality, derived-wood properties have been estimated based on anatomical characteristics [8-18]. Fibres with high Runkel ratios are stiffer and less flexible, resulting in bulkier paper with the area having a weak bond [10]. A low Luce's shape factor indicates low resistance to beating in papermaking [11]. The flexibility coefficient expresses the potential of fibre to collapse during beating $[10,12]$. Collapsed fibres produce paper with high strength [10]. Malan and Gerischer [12] reported that the slenderness ratio is related to the tearing strength and folding endurance of paper. The solids factor is important for predicting sheet density [9]. Wall coverage ratio is one of the indices for bending resistance [8].

The suitability of wood from Acacia melanoxylon [19] and Eucalyptus spp. [20] as raw material for pulp and paper products has been evaluated in previous studies by principal component analysis (PCA) using anatomical characteristics, chemical characteristics, and wood properties as variables. For example, Carrillo et al. [20] examined the wood properties and fibre quality of 6-year-old E. globulus and E. nitens trees using PCA. Most E. nitens trees showed principal component (PC) 1 values that indicate basic density, while most E. globulus trees showed higher PC2 values, which indicate fibre quality and stem diameter. Regarding E. camaldulensis, several studies have been conducted on anatomical characteristics, derived-wood properties, and wood properties for the improvement of pulp and paper quality [5,9,13-15,21-24]. We also clarified among-family variations in the basic density and lignin content of E. camaldulensis [5,25]. However, the suitability of wood as raw material for pulp and paper products in E. camaldulensis families or clones has not yet been evaluated by PCA. Further detailed research is needed to not only clarify anatomical characteristics and wood properties but also evaluate the suitability of wood as raw material for pulp and paper. Such research should be based on PCA analysis and use these characteristics and properties of E. camaldulensis half-sib families as variables.

In this study, anatomical characteristics and derived-wood properties were investigated for 5-year-old E. camaldulensis trees from 15 half-sib families. Based on the PCA and clustering results using the obtained anatomical characteristic data, the yield and quality of pulp and paper were estimated in each family to clarify the suitability of wood in each family as raw materials for pulp and paper.

\section{Materials and Methods}

\subsection{Wood Sampling}

The progeny test site of second-generation Eucalyptus camaldulensis Dehnh. was located in Wang Nam Khieo, Nakhon Ratchsima, Thailand $\left(14^{\circ} 30^{\prime}\right.$ N, $101^{\circ} 56^{\prime}$ E). Figure 1 shows the climate data of Nakhon Ratchsima, Thailand [26]. The test site was established in 2006 with 120 half-sib families selected as plus trees from Australia and Thailand based on growth characteristics [6]. Trees were planted with an initial spacing of $3.0 \mathrm{~m} \times 1.5 \mathrm{~m}$. In 2010, a thinning treatment was conducted, and eight trees in each family remained with spacing of around $3.0 \mathrm{~m} \times 4.5 \mathrm{~m}$ after thinning. 


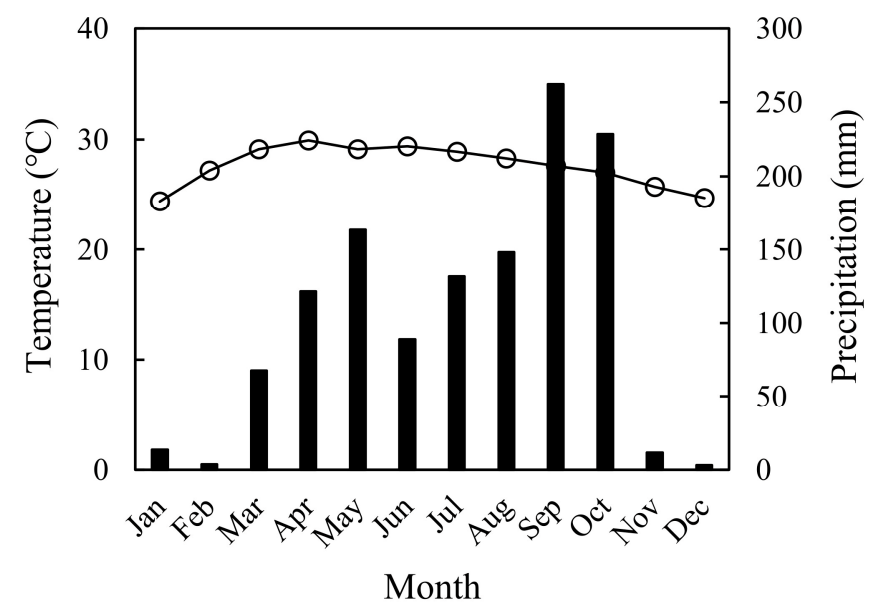

Figure 1. Monthly mean temperature and precipitation in Nakhon Ratchsima $\left(14^{\circ} 58^{\prime} \mathrm{N}, 102^{\circ} 04^{\prime} \mathrm{E}\right)$, Thailand. Climate data were provided from Japan Meteorological Agency [26]. Mean monthly temperature and precipitation were calculate by averaging monthly values from 2006 to 2010. Circles indicate mean value of temperature. Bars indicate mean value of precipitation.

Of the 120 half-sib families, 15 families were selected for their superior growth and physiological characteristics at age 5 . Stem diameter at $1.3 \mathrm{~m}$ above the ground and tree height were measured for six trees in each family in July 2011 [5]. Of the measured trees, five trees in each family were selected for average stem diameter within a family, and a total of 75 trees from 15 families were used. Two core samples $(5 \mathrm{~mm}$ in diameter and $2 \mathrm{~cm}$ in length from the cambium) were collected in different circumferential positions at $1.3 \mathrm{~m}$ above the ground using an increment borer (Haglöf, Långsele, Sweden). One core sample was used to determine basic density, and the other core sample was used for determining fibre length, lignin content, vessel frequency, vessel diameter, fibre diameter, fibre lumen diameter, and fibre wall thickness. For analysing anatomical characteristics, core samples were divided into two small segments $(1 \mathrm{~cm}$ in length). Anatomical characteristics were measured in both core samples in a tree. Lignin contents were determined by wood obtained from the trimming of the surface of core samples for determining anatomical characteristics. Of these factors, basic density, fibre length, and lignin content (determined by the acetyl bromide method [27]) were investigated by Kuramochi et al. [5] (Table 1).

\subsection{Anatomical Characteristics}

Figure 2 shows transverse image of E. camaldulensis. The secondary xylem of $E$. camaldulensis consisted of vessel, wood fibre, ray parenchyma, and axial parenchyma cells (Figure 2A) [28]. To determine vessel frequency, vessel diameter, fibre diameter, fibre lumen diameter, and fibre wall thickness, the transverse surface of the small samples was trimmed with a sliding microtome (ROM-380, Yamamotokohki, Saitama, Japan). The trimmed samples were dehydrated using a graded ethanol series, followed by absolute ethanol and acetone, and then the dehydrated samples were coated with gold using a sputter coater (SC-701Mk II, Sanyu Electron, Tokyo, Japan). Transverse images of the samples were taken using a scanning electron microscope (JCM-5000, JEOL, Tokyo, Japan) with an acceleration voltage of $5-15 \mathrm{kV}$ to determine the anatomical characteristics. Two photomicrographs with $\times 34,20$ photomicrographs with $\times 300$, and six photomicrographs with $\times 600$ were taken for determining vessel frequency, vessel diameter, and fibre morphologies (fibre/lumen diameter and fibre wall thickness), respectively. The transverse images were stored on a personal computer, and then the morphology of the vessels and fibres was determined using image analysis software (ImageJ, National Institutes of Health, Bethesda, MD, USA). Vessel diameter was determined by averaging the radial diameter and tangential diameter (Figure 2B). The transverse sectional shape of the fibre and fibre lumen (Figure 2C) was assumed to be an ellipse, and then the major and minor radii were estimated by the 
software. The fibre and fibre lumen diameters were determined by averaging the major and minor radii, respectively. Each whole fibre wall region was regarded as a trapezoid, the fibre wall thickness was calculated as the height of the trapezoid using the method described by Yoshinaga et al. [29]. To determine the vessel frequency, the number of vessels in the digital images were counted, and then the number of vessels was divided by the area of the digital image. In addition, three digital images at each radial position were used to determine vessel frequency. The vessel diameter was measured for 30 vessels, while fibre diameter, fibre lumen diameter, and fibre wall thickness were measured for 50 wood fibres.

Table 1. Family mean values and repeatabilities (R) of stem diameter over bark at $1.3 \mathrm{~m}$ above the ground $(D)$, tree height $(T H)$, basic density $(B D)$, fibre length $(F L)$, and lignin content $(L C)$ in 15 half-sib families (modified from Kuramochi et al. [5]).

\begin{tabular}{|c|c|c|c|c|c|c|c|c|c|c|}
\hline \multirow{2}{*}{ Family ID } & \multicolumn{2}{|c|}{$D(\mathrm{~cm})$} & \multicolumn{2}{|c|}{$T H(\mathrm{~m})$} & \multicolumn{2}{|c|}{$B D\left(\mathrm{~g} / \mathrm{cm}^{3}\right)$} & \multicolumn{2}{|c|}{$F L(\mathrm{~mm})$} & \multicolumn{2}{|c|}{$\operatorname{LC}(\%)$} \\
\hline & Mean & SD & Mean & SD & Mean & SD & Mean & SD & Mean & SD \\
\hline 26 & 11.2 & 0.6 & 16.1 & 1.6 & 0.58 & 0.05 & 0.94 & 0.08 & 27.3 & 2.8 \\
\hline 61 & 10.7 & 0.8 & 15.0 & 2.0 & 0.57 & 0.04 & 0.96 & 0.04 & 29.4 & 3.5 \\
\hline 64 & 10.2 & 0.8 & 14.5 & 0.5 & 0.57 & 0.02 & 0.95 & 0.05 & 29.4 & 2.8 \\
\hline 88 & 10.1 & 0.4 & 14.7 & 0.6 & 0.57 & 0.05 & 1.03 & 0.07 & 28.8 & 4.7 \\
\hline 99 & 10.1 & 0.5 & 14.8 & 0.8 & 0.60 & 0.07 & 0.87 & 0.06 & 26.5 & 1.5 \\
\hline 126 & 9.6 & 1.4 & 15.7 & 1.0 & 0.51 & 0.03 & 0.90 & 0.06 & 30.2 & 1.6 \\
\hline 129 & 10.6 & 0.9 & 14.8 & 1.3 & 0.53 & 0.05 & 0.91 & 0.08 & 30.0 & 1.6 \\
\hline 155 & 10.2 & 0.8 & 15.4 & 1.2 & 0.53 & 0.05 & 0.91 & 0.08 & 30.2 & 2.0 \\
\hline 179 & 9.7 & 0.5 & 14.5 & 1.3 & 0.58 & 0.04 & 0.94 & 0.06 & 27.2 & 1.8 \\
\hline 184 & 10.5 & 1.3 & 13.9 & 1.5 & 0.54 & 0.03 & 0.93 & 0.04 & 29.5 & 2.4 \\
\hline 203 & 11.1 & 1.0 & 15.6 & 0.7 & 0.56 & 0.03 & 0.95 & 0.04 & 27.0 & 2.5 \\
\hline 219 & 10.8 & 1.2 & 15.0 & 1.6 & 0.58 & 0.03 & 0.94 & 0.03 & 29.7 & 2.0 \\
\hline 227 & 10.4 & 1.7 & 14.9 & 1.0 & 0.61 & 0.05 & 1.00 & 0.05 & 29.5 & 2.7 \\
\hline 236 & 10.6 & 0.9 & 17.0 & 1.7 & 0.55 & 0.04 & 0.95 & 0.05 & 30.5 & 2.2 \\
\hline 996 & 9.1 & 0.9 & 13.9 & 1.4 & 0.57 & 0.02 & 0.98 & 0.06 & 29.3 & 2.3 \\
\hline Mean/total & 10.3 & 0.6 & 15.1 & 0.8 & 0.56 & 0.03 & 0.94 & 0.04 & 29.0 & 1.3 \\
\hline$F$-values & \multicolumn{2}{|c|}{1.626} & \multicolumn{2}{|c|}{2.014} & \multicolumn{2}{|c|}{2.200} & \multicolumn{2}{|c|}{2.366} & \multicolumn{2}{|c|}{1.292} \\
\hline$p$-values & \multicolumn{2}{|c|}{0.098} & \multicolumn{2}{|c|}{0.032} & \multicolumn{2}{|c|}{0.018} & \multicolumn{2}{|c|}{0.011} & \multicolumn{2}{|c|}{0.239} \\
\hline $\mathrm{R}$ & \multicolumn{2}{|c|}{0.11} & \multicolumn{2}{|c|}{0.17} & \multicolumn{2}{|c|}{0.13} & \multicolumn{2}{|c|}{0.21} & \multicolumn{2}{|c|}{0.06} \\
\hline
\end{tabular}

The mean and standard deviation (SD) for each family were recalculated for five trees used in the present study from data of six trees published in a previous paper [5]. Mean/total values were calculated based on the mean values of all 15 families. Basic density was determined as the ratio of oven-dry weight to green volume, as measured by the water displacement method described by Takeuchi et al. [18].
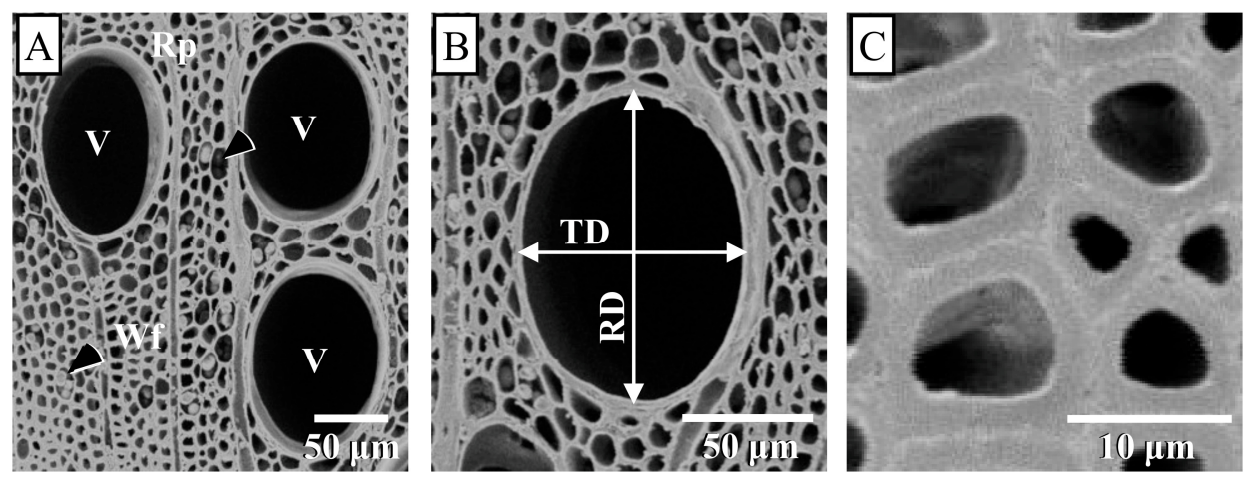

Figure 2. Scanning electron photomicrographs of transverse sections of E. camaldulensis. (A), types of cells; (B), tangential diameter (TD) and radial diameter (RD) of a vessel; (C), wood fibres. V, vessel; Wf, wood fibre; Rp, ray parenchyma; arrow heads, axial parenchyma.

\subsection{Derived-Wood Properties}

The following derived-wood properties related to pulp and paper quality were determined [14,15,18]: Runkel ratio [30], Luce's shape factor [11], flexibility coefficient [12], 
slenderness ratio [12], solids factor [31], and wall coverage ratio [8]. Their calculation formulas are listed in Table $2[8,9,11,12,18,30-33]$.

Table 2. Relationships between pulp and paper quality and measured properties as well as the calculation formulas for derived-wood properties.

\begin{tabular}{cccc}
\hline Property & Formula & Relation to Pulp and Paper Quality & Reference \\
\hline Stem diameter & - & Pulp yield $(+)$ & {$[32]$} \\
Basic density & - & Pulp yield $(+)$ & {$[31]$} \\
Lignin content & - & Digestibility $(-)$ & {$[33]$} \\
Fibre length & - & Paper strength $(+)$ & {$[9]$} \\
Vessel diameter & - & Vessel picking $(+)$ & {$[8]$} \\
Runkel ratio & $\frac{2 \times F W T}{F L D}$ & Pulp yield (+) and digestibility $(-)$ & {$[30]$} \\
Luce's shape factor & $\frac{F D^{2}-F L D^{2}}{F D^{2}+F L D^{2}}$ & Resistance to beating $(+)$ & {$[11]$} \\
Flexibility coefficient & $\frac{F L D}{F D}$ & Tearing and tensile strength $(+)$ & {$[12]$} \\
Slenderness ratio & $\frac{F L}{F D}$ & Tearing strength $(+)$ & {$[9,12]$} \\
Solids factor & $\left(F D^{2}-\frac{F L D^{2}}{F D}\right) \times F L$ & Sheet density $(-)$ & {$[9,31]$} \\
Wall coverage ratio & $\frac{2 \times F W T}{F D}$ & Bending resistance $(-)$ & {$[8]$} \\
\hline
\end{tabular}

$F W T$, fibre wall thickness; $F L D$, fibre lumen diameter; $F D$, fibre diameter; $F L$, fibre length; $(+),(-)$, positively or negatively related to pulp and paper quality (modified from Takeuchi et al. [18]).

\subsection{Data Analysis}

Data of stem diameter, tree height, basic density, lignin content, and fibre length in five trees used in the present study were recalculated from the data published in a previous paper (Table 1, [5]). The mean values of anatomical characteristics and derived-wood properties in each radial position were calculated, and then mean value of a tree was calculated by averaging the two radial positions in a tree. The mean values in a tree in each characteristic or property were used for following statistical analysis. A one-way analysis of variance (ANOVA) test was performed to detect among-family variation in each anatomical characteristic and derived-wood property. The repeatability of each characteristic was calculated as the ratio of family variance to total variance (family variance + residual variance) [34]. PCA was applied to the data to clarify the suitability of wood as raw material for pulp and paper products. The following measured properties were selected as variables for PCA: (1) properties showing significant differences among families and (2) properties known to be important for the yield and quality of pulp and paper. The principal component scores were calculated, and then cluster analysis was conducted using Euclidean distance and Ward's linkage method to classify the families into clusters. All statistical analyses were performed using R statistical software [35].

\section{Results and Discussion}

\subsection{Anatomical Characteristics and Derived-Wood Properties}

Table 3 shows the mean values of anatomical characteristics for each family. The mean values of all 15 families were $128 \mu \mathrm{m}, 16 \mathrm{no} . / \mathrm{mm}^{2}, 11.1 \mu \mathrm{m}, 7.1 \mu \mathrm{m}$, and $1.88 \mu \mathrm{m}$ for vessel diameter, vessel frequency, fibre diameter, fibre lumen diameter, and fibre wall thickness, respectively. It was reported that the clonal mean value ranges of tangential vessel diameter, vessel frequency, fibre diameter, and fibre wall thickness in five clones of 5-year-old E. camaldulensis trees planted in Thailand were $89-101 \mu \mathrm{m}, 14-16 \mathrm{no} . / \mathrm{mm}^{2}, 11.4-12.3 \mu \mathrm{m}$, and 2.2-2.6 $\mu \mathrm{m}$, respectively [23,24]. In 6- to 8-year-old E. camaldulensis trees planted in Morocco, fibre width, fibre lumen width, and wall thickness were 10.1, 5.5, and $2.3 \mu \mathrm{m}$, respectively [13]. The anatomical characteristics at the outermost part $(2 \mathrm{~cm}$ in length from the cambium) of the stem in the 5-year-old plantation-grown E. camaldulensis trees examined in the present study (Table 3) were similar to those obtained for similar-age trees from this species in previous studies $[13,23,24]$. However, several researchers reported that anatomical characteristics' values varied from pith to bark in E. camaldulensis [14,21-25,36]. 
Thus, the obtained mean values in the present study are not considered as whole-tree values in this species.

Table 3. Family mean values and repeatabilities (R) of the anatomical characteristics of 15 half-sib families.

\begin{tabular}{|c|c|c|c|c|c|c|c|c|c|c|}
\hline \multirow{2}{*}{ Family ID } & \multicolumn{2}{|c|}{$V D(\mu \mathrm{m})$} & \multicolumn{2}{|c|}{$V F\left(\right.$ no. $\left./ \mathrm{mm}^{2}\right)$} & \multicolumn{2}{|c|}{$F D(\mu \mathrm{m})$} & \multicolumn{2}{|c|}{$F L D(\mu \mathrm{m})$} & \multicolumn{2}{|c|}{$F W T(\mu \mathrm{m})$} \\
\hline & Mean & SD & Mean & SD & Mean & SD & Mean & SD & Mean & SD \\
\hline 26 & 134 & 9 & 15 & 3 & 10.9 & 0.4 & 6.5 & 0.5 & 2.07 & 0.13 \\
\hline 61 & 130 & 10 & 17 & 1 & 11.2 & 0.3 & 7.3 & 0.6 & 1.91 & 0.25 \\
\hline 64 & 126 & 9 & 17 & 2 & 11.0 & 0.6 & 7.2 & 0.4 & 1.81 & 0.15 \\
\hline 88 & 132 & 12 & 16 & 3 & 11.2 & 0.5 & 6.9 & 0.4 & 2.01 & 0.26 \\
\hline 99 & 119 & 11 & 18 & 3 & 10.6 & 0.8 & 6.4 & 1.0 & 1.99 & 0.18 \\
\hline 126 & 122 & 13 & 16 & 3 & 11.7 & 0.4 & 8.0 & 0.6 & 1.76 & 0.16 \\
\hline 129 & 125 & 21 & 17 & 4 & 10.6 & 0.4 & 6.9 & 0.6 & 1.75 & 0.15 \\
\hline 155 & 135 & 11 & 16 & 4 & 10.9 & 0.8 & 7.4 & 0.6 & 1.68 & 0.32 \\
\hline 179 & 123 & 6 & 18 & 3 & 11.0 & 0.6 & 7.1 & 1.0 & 1.88 & 0.27 \\
\hline 184 & 126 & 8 & 17 & 2 & 11.0 & 0.5 & 7.1 & 0.5 & 1.86 & 0.08 \\
\hline 203 & 133 & 28 & 14 & 3 & 11.1 & 0.3 & 7.3 & 0.3 & 1.82 & 0.05 \\
\hline 219 & 130 & 9 & 17 & 2 & 10.9 & 0.8 & 7.0 & 0.7 & 1.88 & 0.22 \\
\hline 227 & 123 & 13 & 17 & 3 & 11.2 & 0.5 & 7.2 & 0.5 & 1.91 & 0.10 \\
\hline 236 & 131 & 12 & 16 & 3 & 11.8 & 0.6 & 7.7 & 0.6 & 1.96 & 0.16 \\
\hline 996 & 128 & 13 & 16 & 3 & 10.8 & 0.6 & 6.9 & 0.3 & 1.84 & 0.23 \\
\hline Mean/total & 128 & 5 & 16 & 1 & 11.1 & 0.3 & 7.1 & 0.4 & 1.88 & 0.11 \\
\hline$F$-values & \multicolumn{2}{|c|}{0.677} & \multicolumn{2}{|c|}{0.834} & \multicolumn{2}{|c|}{1.927} & \multicolumn{2}{|c|}{2.138} & \multicolumn{2}{|c|}{1.665} \\
\hline$p$-values & \multicolumn{2}{|c|}{0.787} & \multicolumn{2}{|c|}{0.631} & \multicolumn{2}{|c|}{0.041} & \multicolumn{2}{|c|}{0.022} & \multicolumn{2}{|c|}{0.088} \\
\hline $\mathrm{R}$ & \multicolumn{2}{|c|}{-0.07} & \multicolumn{2}{|c|}{-0.03} & \multicolumn{2}{|c|}{0.16} & \multicolumn{2}{|c|}{0.19} & \multicolumn{2}{|c|}{0.12} \\
\hline
\end{tabular}

$V D$, vessel diameter; $V F$, vessel frequency; $F D$, fibre diameter; $F L D$, fibre lumen diameter; $F W T$, fibre wall thickness. The mean and standard deviation (SD) for each family were calculated based on data from five trees in the family. Mean/total values were calculated based on the mean values for all 15 families.

The derived-wood properties of 14-year-old E. camaldulensis trees grown in Australia were examined by Ohshima et al. [14,15]. They reported that Runkel ratio, Luce's shape factor, flexibility coefficient, slenderness ratio, solids factor, and wall coverage ratio for two trees were $0.50,0.37,0.68,50.5-56.6,48.6-51.2 \times 10^{3} \mu \mathrm{m}^{3}$, and 0.32 , respectively. In this study, family mean value ranges of the Runkel ratio, Luce's shape factor, flexibility coefficient, slenderness ratio, solids factor, and wall coverage ratio were $0.44-0.64,0.36-0.47$, $0.60-0.68,76.5-92.2,59-80 \times 10^{3} \mu^{3}$, and $0.30-0.38$, respectively (Table 4$)$. The results obtained in the present study were similar to those reported by Ohshima et al. [14,15], except for the slenderness ratio and solids factor (Table 4). Slenderness ratio and solids factor were calculated by fibre length and fibre/lumen diameter. The fibre length in the present study was longer than that reported by Ohshima et al. [22], although wood fibre and fibre lumen diameter had almost the same values in both studies [21], indicating that the slenderness ratio and solids factor values in E. camaldulensis trees at age 5 were higher than those in Ohshima et al. [14]. Based on these results, it is believed that paper with good tearing strength and low sheet density can be obtained from 5-year-old trees from $E$. camaldulensis families. It is well known that wood with a Runkel ratio of less than 1.0 and a wall coverage ratio of less than 0.4 is suitable for papermaking $[30,37]$. The results of this study satisfied these two criteria (Table 4), suggesting that the wood obtained from these families is suitable for papermaking. 
Table 4. Family mean values and repeatabilities (R) of the derived-wood properties of 15 half-sib families.

\begin{tabular}{|c|c|c|c|c|c|c|c|c|c|c|c|c|}
\hline \multirow{2}{*}{ Family ID } & \multicolumn{2}{|c|}{$R R$} & \multicolumn{2}{|c|}{$L S F$} & \multicolumn{2}{|c|}{$F C$} & \multicolumn{2}{|c|}{$S R$} & \multicolumn{2}{|c|}{$S F\left(\times 10^{3} \mu \mathrm{m}^{3}\right)$} & \multicolumn{2}{|c|}{ WCR } \\
\hline & Mean & SD & Mean & SD & Mean & SD & Mean & SD & Mean & SD & Mean & SD \\
\hline 26 & 0.64 & 0.08 & 0.47 & 0.04 & 0.60 & 0.03 & 86.1 & 6.0 & 72 & 10 & 0.38 & 0.03 \\
\hline 61 & 0.53 & 0.11 & 0.41 & 0.06 & 0.65 & 0.05 & 85.5 & 5.5 & 71 & 8 & 0.34 & 0.04 \\
\hline 64 & 0.50 & 0.05 & 0.40 & 0.03 & 0.66 & 0.02 & 86.5 & 2.7 & 67 & 11 & 0.33 & 0.02 \\
\hline 88 & 0.58 & 0.10 & 0.44 & 0.05 & 0.62 & 0.04 & 92.2 & 8.0 & 80 & 14 & 0.36 & 0.04 \\
\hline 99 & 0.64 & 0.14 & 0.47 & 0.07 & 0.60 & 0.05 & 82.6 & 5.8 & 62 & 9 & 0.38 & 0.05 \\
\hline 126 & 0.44 & 0.07 & 0.36 & 0.04 & 0.68 & 0.03 & 76.5 & 4.2 & 66 & 8 & 0.30 & 0.03 \\
\hline 129 & 0.51 & 0.09 & 0.41 & 0.05 & 0.65 & 0.04 & 86.0 & 10.2 & 59 & 6 & 0.33 & 0.04 \\
\hline 155 & 0.46 & 0.11 & 0.37 & 0.06 & 0.68 & 0.05 & 82.8 & 5.9 & 60 & 18 & 0.30 & 0.05 \\
\hline 179 & 0.55 & 0.17 & 0.42 & 0.09 & 0.64 & 0.07 & 85.2 & 7.1 & 67 & 9 & 0.34 & 0.06 \\
\hline 184 & 0.53 & 0.04 & 0.41 & 0.02 & 0.64 & 0.02 & 84.9 & 6.7 & 66 & 3 & 0.34 & 0.02 \\
\hline 203 & 0.50 & 0.03 & 0.40 & 0.02 & 0.66 & 0.02 & 85.4 & 4.8 & 67 & 5 & 0.33 & 0.01 \\
\hline 219 & 0.54 & 0.09 & 0.42 & 0.05 & 0.64 & 0.04 & 85.9 & 5.0 & 67 & 13 & 0.34 & 0.03 \\
\hline 227 & 0.53 & 0.06 & 0.42 & 0.03 & 0.64 & 0.02 & 88.7 & 7.1 & 74 & 4 & 0.34 & 0.03 \\
\hline 236 & 0.51 & 0.06 & 0.41 & 0.04 & 0.65 & 0.03 & 81.0 & 7.1 & 77 & 6 & 0.33 & 0.03 \\
\hline 996 & 0.53 & 0.07 & 0.42 & 0.04 & 0.64 & 0.03 & 90.7 & 5.9 & 68 & 12 & 0.34 & 0.03 \\
\hline Mean/total & 0.53 & 0.06 & 0.42 & 0.03 & 0.64 & 0.02 & 85.3 & 3.8 & 68 & 6 & 0.34 & 0.02 \\
\hline$F$-values & \multicolumn{2}{|c|}{1.872} & \multicolumn{2}{|c|}{1.855} & \multicolumn{2}{|c|}{1.858} & \multicolumn{2}{|c|}{1.762} & \multicolumn{2}{|c|}{1.706} & \multicolumn{2}{|c|}{1.781} \\
\hline$p$-values & \multicolumn{2}{|c|}{0.048} & \multicolumn{2}{|c|}{0.051} & \multicolumn{2}{|c|}{0.050} & \multicolumn{2}{|c|}{0.067} & \multicolumn{2}{|c|}{0.078} & \multicolumn{2}{|c|}{0.063} \\
\hline $\mathrm{R}$ & \multicolumn{2}{|c|}{0.15} & \multicolumn{2}{|c|}{0.15} & \multicolumn{2}{|c|}{0.15} & \multicolumn{2}{|c|}{0.13} & \multicolumn{2}{|c|}{0.12} & \multicolumn{2}{|c|}{0.14} \\
\hline
\end{tabular}

$R R$, Runkel ratio; $L S F$, Luce's shape factor; $F C$, flexibility coefficient; $S R$, slenderness ratio; $S F$, solids factor; $W C R$, wall coverage ratio. The mean and standard deviation (SD) for each family were calculated based on data from five trees in the family. Mean/total values were calculated based on the mean values for all 15 families.

Veenin et al. [23] found that, in 5-year-old E. camaldulensis clones, tangential vessel diameter and vessel frequency did not significantly differ, while a significant difference was found for fibre diameter. In this study, significant among-family variations were found in fibre diameter and fibre lumen diameter (Table 3), considering that pulp and paper quality related to fibre diameter and fibre lumen diameter differ among families. The $p$-values obtained by an ANOVA test in many derived-wood properties ranged from 0.048 to 0.078 (Table 4), suggesting that the quality of pulp and paper produced from the wood of this species can be improved through the improvement of fibre morphologies under appropriate tree breeding programmes. Similar results were obtained by Varghese et al. [38]: pulp yield, basic density, and lignin contents in E. camaldulensis can be improved by the selection of families according to growth characteristics as well as wood properties.

\subsection{Statistic Classification of Families in Regard to Expected Pulp and Paper Quality}

Results of the PCA are shown in Figure 3 and Table 5. The following properties were used as variables: stem diameter, basic density, lignin content, vessel diameter, fibre length, and Runkel ratio. The absolute loading values for PC1 were high for basic density, lignin content and Runkel ratio (Table 5). For PC2, the loading values for stem diameter, fibre length, and vessel diameter were high (Table 5). The first and second principal components explained $37.7 \%$ and $26.6 \%$, respectively (Figure 3). As shown in Figure 3, 15 families were classified into two types: (1) families near the origin (i.e., the values of PC1 and PC2 were both 0 ) and (2) families separated from the origin. Fifteen families were clarified into four clusters: cluster D (family IDs: 61, 64, 219, 227, 236, and 996) was located near the origin, whereas clusters A (family IDs: 126, 129, 155, and 184), B (family IDs: 99 and 179), and C (family IDs: 26, 88, and 203) were scattered (Figures 3 and 4). Based on these results, the expected characteristics of pulp and paper in each family were examined (Table 6). The fact that the families in cluster D were located near the origin suggests that the wood from these families has average pulp and paper quality in relation to the 15 families used in this study. Cluster B included families 99 and 179, and wood from these families may provide high pulp yield and good digestibility and low strength and vessel picking frequency. Thus, 
this wood is suitable for producing paper for which less strength is acceptable. Cluster C, comprised of families 26,88 , and 203, can achieve the highest pulp yield, with good digestibility and high strength properties. Families 126, 129, 155, and 184 in cluster A provide low pulp yield, digestibility, and vessel pick frequency, indicating that the wood is not suitable for efficient pulp production.

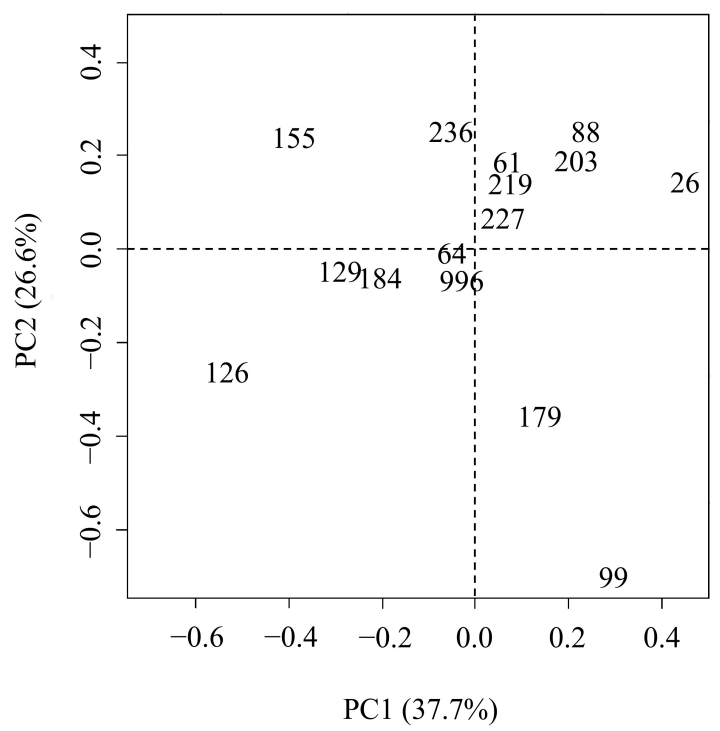

Figure 3. Principal component analysis scores for selected traits. PC, principal component. Numbers in the figure indicate family IDs.

Table 5. Loading values of principal component analysis for 15 families.

\begin{tabular}{ccc}
\hline Variables & PC1 & PC2 \\
\hline Stem diameter & 0.245 & 0.384 \\
Basic density & 0.552 & - \\
Lignin content & -0.508 & 0.354 \\
Fibre length & 0.220 & 0.461 \\
Vessel diameter & 0.107 & 0.683 \\
Runkel ratio & 0.563 & -0.213 \\
\hline
\end{tabular}

PC, principal component; -, approximately 0.

Table 6. Expected characteristics of pulp and paper in each family.

\begin{tabular}{|c|c|c|c|c|}
\hline \multirow{2}{*}{$\begin{array}{c}\text { Expected Characteristics of } \\
\text { Pulp and Paper }\end{array}$} & \multicolumn{4}{|c|}{ Cluster } \\
\hline & A & B & $\mathrm{C}$ & D \\
\hline Pulp yield & - & ++ & +++ & + \\
\hline Digestibility & - & ++ & ++ & + \\
\hline Paper strength & + & - & ++ & + \\
\hline Vessel picking & ++ & ++ & - & + \\
\hline $\begin{array}{l}\text { Expected characteristics } \\
\text { of products }\end{array}$ & $\begin{array}{l}\text { Pulp with } \\
\text { poor yield }\end{array}$ & $\begin{array}{l}\text { Paper without high } \\
\text { strength properties }\end{array}$ & $\begin{array}{l}\text { The most desirable paper } \\
\text { except for vessel pick }\end{array}$ & $\begin{array}{l}\text { Average pulp } \\
\text { and paper }\end{array}$ \\
\hline
\end{tabular}

The letters A-D indicate cluster means. +++, very good; ++, good; +, acceptable; -, bad. 


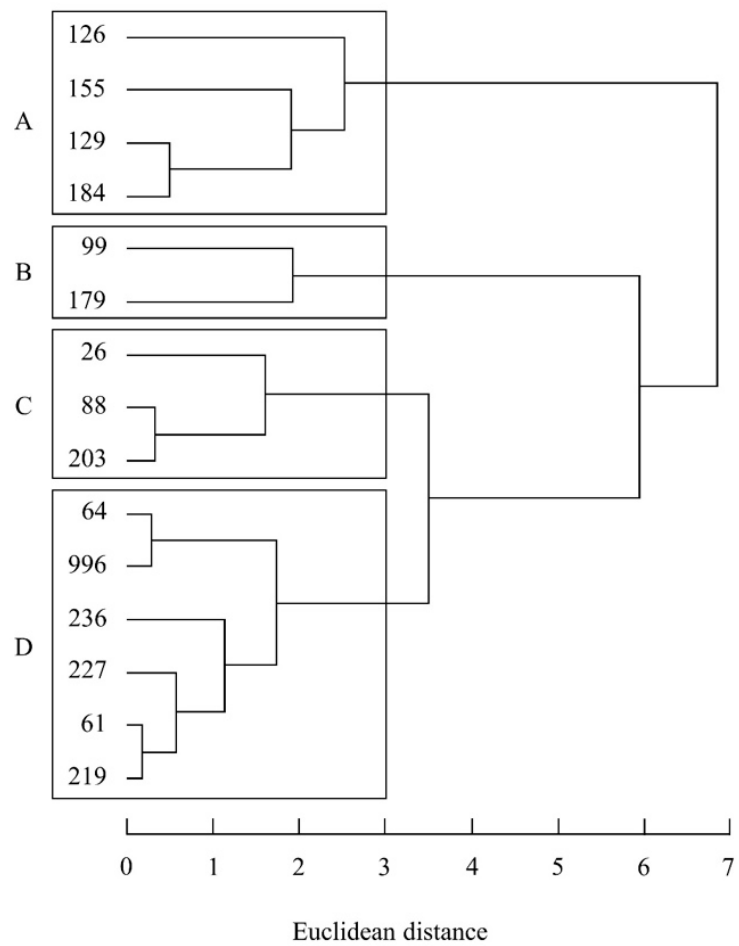

Figure 4. Dendrogram based on the principal component scores shown in Figure 3. Numbers in the figure indicate family IDs. Boxes indicate the same clusters. The letters (A-D) indicate cluster means.

The results obtained in this study suggest that the expected characteristics of pulp and paper products differ among the families. Thus, the suitability of wood as a raw material for pulp and paper should be evaluated by PCA and clustering based on the specific wood properties and anatomical characteristics of E. camaldulensis families. These results can be used for preliminary family selection in this species to produce wood that leads to desirable pulp and paper quality.

\section{Conclusions}

The anatomical characteristics and derived-wood properties of E. camaldulensis trees from 15 half-sib families were investigated. Among the families, significant differences were found in fibre diameter, fibre lumen diameter, and Runkel ratio. In addition, relatively lower $p$-values obtained by ANOVA test were also found in flexibility coefficient (0.050), Luce's shape factor (0.051), wall coverage ratio (0.063), slenderness ratio $(0.067)$, solids factor (0.078), and fibre wall thickness (0.088). These results indicated that pulp and paper quality might be improved by selecting families with good anatomical characteristics. The PCA and cluster analysis examined several properties related to pulp and paper quality. Based on the expected pulp and paper quality, the 15 families were classified into four clusters: average pulp and paper (cluster D); paper with less required strength (cluster B); the most desirable paper, except for vessel picking frequency (cluster $\mathrm{C}$ ); and pulp with poor yield (cluster A). The results indicate that the pulp and paper quality achieved through the use of wood from E. camaldulensis half-sib families may be improved by appropriate tree breeding programmes. In addition, the results can contribute to the sustainable supply of pulpwood from fast-growing tree plantations to pulp and paper industries.

Author Contributions: Conceptualisation, F.I. and S.D.; formal analysis, I.N., F.I., and H.A.; investigation, I.N., F.I., and H.A.; methodology, F.I. and S.D.; resources, S.D.; writing-original draft, I.N., F.I., and H.A.; writing-review and editing, S.D., J.O., K.I., and S.Y. All authors have read and agreed to the published version of the manuscript.

Funding: This research received no external funding. 
Institutional Review Board Statement: Not applicable.

Informed Consent Statement: Not applicable.

Data Availability Statement: The data presented in this study are available on request from the corresponding author.

Acknowledgments: We are grateful to the staff and students of the Faculty of Forestry, Kasetsart University, Forestry, and School of Agriculture, Utsunomiya University, for their help with the field sampling and laboratory experiments.

Conflicts of Interest: The authors declare no conflict of interest.

\section{References}

1. FAOSTAT. Forestry Production and Trade. Available online: http://www.fao.org/faostat/en/\#data/FO (accessed on 29 November 2020).

2. Cossalter, C.; Pye-Smith, C. Fast-Wood Forestry Myths and Realities; Center for International Forestry Research: Bogor, Indonesia, 2003; pp. 1-50.

3. FAO. Global Forest Resources Assessments. Available online: http://www.fao.org/forest-resources-assessment/pastassessments/fra-2000/en/ (accessed on 20 December 2020).

4. Turnbull, J.W.; Pryor, L.D. Choice of species and seed sources. In Eucalyptus for Wood Production; Hillis, W.E., Brown, A.G., Eds.; Academic Press: Sydney, Australia, 1984; pp. 6-65.

5. Kuramochi, U.; Aiso, H.; Diloksumpun, S.; Tanabe, J.; Ohshima, J.; Ishiguri, F.; Takashima, Y.; Iizuka, K.; Yokota, S.; Aizawa, M.; et al. Among-family variation of wood properties relating to pulp qualities in 5-year-old Eucalyptus camaldulensis planted in the northeastern region of Thailand. For. Genet. Tree Breed. 2014, 3, 146-152.

6. Sungtong, T.; Diloksumpun, S. Variations in physiological characteristics of different Eucalyptus camaldulensis Dehnh. half-sib families. Thai J. 2011, 30, 1-13.

7. Pinyopusarerk, K.; Doran, J.C.; Williams, E.R.; Wasuwanich, P. Variation in growth of Eucalyptus camaldulensis provenances in Thailand. Ecol. Manag. 1996, 87, 63-73. [CrossRef]

8. Hudson, I.; Wilson, L.; Beveren, K.V. Vessel and fibre property variation in Eucalyptus globulus and Eucalyptus nitens: Some preliminary results. Iawa J. 1998, 19, 111-130. [CrossRef]

9. Ona, T.; Sonoda, T.; Ito, K.; Shibata, M.; Tamai, Y.; Kojima, Y.; Ohshima, J.; Yokota, S.; Yoshizawa, N. Investigation of relationship between cell and pulp properties in Eucalyptus by examination of within-tree property variations. Wood Sci. Technol. 2001, 35, 229-243. [CrossRef]

10. Ashori, A.; Nourbakhsh, A. Studies on Iranian cultivated paulownia: A potential of fibrous raw material for paper industry. Eur. J. Wood Prod. 2009, 67, 323-327. [CrossRef]

11. Luce, J.E. Transverse collapse of wood pulp fibres: Fibre models. In The Physics and Chemistry of Wood Pulp Fibres (Special Technical Association Publication, No. 8); Page, D.H., Ed.; Technical Association of the Pulp and Paper Industry: New York, NY, USA, 1970; pp. 278-281.

12. Malan, F.S.; Gerischer, G.F.R. Wood property differences in South African grown Eucalyptus grandis trees of different growth stress intensity. Holzforschung 1987, 41, 331-335. [CrossRef]

13. Moussaouiti, M.E.; Barcha, B.; Alves, E.F.; Francis, R. Kraft pulping characteristics of three Moroccan eucalypti. Part 1: Physical and chemical properties of woods and pulps. BioResources 2012, 7, 1558-1568. [CrossRef]

14. Ohshima, J.; Yokota, S.; Yoshizawa, N.; Ona, T. Examination of within-tree variations and the heights representing whole-tree values of derived wood properties for quasi-non-destructive breeding of Eucalyptus camaldulensis and Eucalyptus globulus as quality pulpwood. J. Wood Sci. 2005, 51, 102-111. [CrossRef]

15. Ohshima, J.; Yokota, S.; Yoshizawa, N.; Ona, T. Representative heights for assessing whole-tree values and the within-tree variations of derived wood properties in Eucalyptus camaldulensis and E. globulus. Wood Fibre Sci. 2005, 37, 51-65.

16. Pirralho, M.; Flores, D.; Sousa, V.B.; Quilho, T.; Knapic, S.; Pereira, H. Evaluation on paper making potential of nine Eucalyptus species based on wood anatomical features. Ind. Crop. Prod. 2014, 54, 327-334. [CrossRef]

17. Prasetyo, A.; Aiso-Sanada, H.; Ishiguri, F.; Wahyudi, I.; Wijaya, I.P.G.; Ohshima, J.; Yokota, S. Variations in anatomical characteristics and predicted paper quality of three Eucalyptus species planted in Indonesia. Wood Sci. Technol. 2019, 53, 1409-1423. [CrossRef]

18. Takeuchi, R.; Wahyudi, I.; Aiso, H.; Ishiguri, F.; Istikowati, W.T.; Ohkubo, T.; Ohshima, J.; Iizuka, K.; Yokota, S. Wood properties related to pulp and paper quality in two Macaranga species naturally regenerated in secondary forests, Central Kalimantan, Indonesia. Tropics 2016, 25, 107-115. [CrossRef]

19. Santos, A.; Anjos, O.; Amaral, M.E.; Gil, N.; Pereira, H.; Simões, R. Influence on pulping yield and pulp properties of wood density of Acacia melanoxylon. J. Wood Sci. 2012, 58, 479-486. [CrossRef]

20. Carrillo, I.; Valenzuela, S.; Elissetche, J.P. Comparative evaluation of Eucalyptus globulus and E. nitens wood and fibre quality. Iawa J. 2017, 38, 105-116. [CrossRef]

21. Ohshima, J.; Yokota, S.; Yoshizawa, N.; Ona, T. Within-tree variation of detailed fibre morphology and the position representing the whole-tree value in Eucalyptus camaldulensis and E. globulus. Appita J. 2003, 56, 476-482. 
22. Ohshima, J.; Yokota, S.; Yoshizawa, N.; Ona, T. Feasibility study of quality plantation pulpwood breeding on fibre length, vessel element length and their ratio sought by within-tree variations in Eucalyptus trees. For. Stud. 2011, 54, 37-47. [CrossRef]

23. Veenin, T.; Fujita, M.; Nobuchi, T.; Siripatanadilok, S. Radial variations of anatomical characteristics and specific gravity in Eucalyptus camaldulensis clones. Iawa J. 2005, 26, 353-361. [CrossRef]

24. Veenin, T.; Siripatanadilok, S.; Tangjaipitak, K. Radial variation of microfibril angle and cell wall thickness in Eucalyptus camaldulensis clones. Thai J. 2013, 32, 24-34.

25. Nezu, I.; Ishiguri, F.; Aiso, H.; Diloksumpun, S.; Ohshima, J.; Iizuka, K.; Yokota, S. Repeatability of growth characteristics and wood properties for solid wood production from Eucalyptus camaldulensis half-sib families growing in Thailand. Silvae Genet. 2020, 69, 36-43. [CrossRef]

26. Japan Meteorological Agency. ClimatView-A Tool for Viewing Monthly Climate Data. Available online: http://ds.data.jma.go. jp/gmd/tcc/tcc/products/climate/climatview/frame.php (accessed on 20 December 2020).

27. Iiyama, K.; Wallis, A.F.A. An improved acetyl bromide procedure for determining lignin in woods and wood pulps. Wood Sci. Technol. 1988, 22, 271-280. [CrossRef]

28. Dadswell, H.E. The Anatomy of Eucalypt Woods; CSIRO: Melbourne, Australia, 1972; pp. 1-28.

29. Yoshinaga, A.; Fujita, M.; Saiki, H. Secondary wall thickening and lignification of oak xylem components during latewood formation. Mokuzai Gakkaishi 1997, 43, 377-383.

30. Runkel, O.H. Über die Herstellung von Zellstoff aus Holz der Gattung Eucalyptus und Versuche mit zwei unterschiedlichen Eucalyptusarten. Das Pap. 1949, 3, 476-490.

31. Barefoot, C.A.; Hitchings, G.R.; Ellwood, L.E. Wood characteristics and kraft paper properties of four selected Loblolly pines: 1 effect of fibre morphology under identical cooking conditions. Tappi 1964, 47, 343-356.

32. Campinhos, E. More wood of better quality: Intensive silviculture with rapid-growth improved Eucalyptus spp. for pulpwood. Tappi 1980, 63, 145-147.

33. Lundquist, K.; Chang, H.-M.; Lin, S.Y. Isolation and Purification. In Methods in Lignin Chemistry; Lin, S.Y., Dence, C.W., Eds.; Springer: Berlin, Germany, 1992; pp. 63-70.

34. Nakagawa, S.; Schielzeth, H. Repeatability for Gaussian and non-Gaussian data: A practical guide for biologists. Biol. Rev. 2010, 85, 935-956. [CrossRef] [PubMed]

35. R Development Core Team. Available online: https:/ /www.R-project.org/ (accessed on 1 March 2020).

36. Moglia, J.G.; Bravo, S.; Gerez, R. Anatomía comparada del leño de dos orígenes selectos de Eucalyptus camaldulensis (Myrtaceae) de dos orígenes, ensayados en Santiago del Estero. Boletín Soc. Argent. Botánica 2008, 43, 239-246.

37. Japan Technical Association of the Pulp and Paper Industry. Genboku and Chouboku (Log. and log Preparation); Japan Technical Association of the Pulp and Paper Industry: Tokyo, Japan, 1969; pp. 1-302.

38. Varghese, M.; Harwood, C.E.; Bush, D.J.; Baltunis, B.; Kamalakannan, R.; Suraj, P.G.; Hegde, D.; Meder, R. Growth and wood properties of natural provenances, local seed sources and clones of Eucalyptus camaldulensis in southern India: Implications for breeding and deployment. New For. 2017, 48, 67-82. [CrossRef] 